\title{
KONSEP EKONOMI PANCASILA
}

\author{
Oleh: \\ Zainol Hasan \& Mahyudi \\ Universitas Ibrahimy Situbondo \\ hasansideas02@gmail.com \& Mahyudiorind@gmail.com
}

\begin{abstract}
:
Pancasila is a philosophy as well as a source of law for all policies that are a reference for state administration, including in the economic field. The Pancasila economy is an economic concept that is explored and built from the values adopted in Indonesian society. It is also built on the values that exist in Indonesian society. That is derived from religious values, norms, customs, or culture. Even though the world economy has become unified and the market has become global, as long as there is an Indonesian nation and state, the concept of Pancasila economy is still dedicated to the Indonesian people. In addition, the economic concept of Pancasila is not only materialistic but also faith and piety. This is moral and ethical for the administration in the economic field. Therefore, the concept of Pancasila economy is controlled by moral and ethical principles
\end{abstract}

Keyword: Kultur, Ekonomi and Pancasila

\section{A. Pendahuluan}

Bangsa Indonesia memiliki ciri khas serta pandangan hidup yang berbeda dengan bangsa lain. Setiap bangsa di dunia dalam hidup bermasyarakat, berbangsa dan bernegara senantiasa memiliki suatu pandangan hidup, filsafat hidup, serta pedoman hidup agar tidak mengalami kebingungan pada kancah masyarakat Internasional. Negara komunisme dan liberalisme meletakkan dasar filsafat negaranya pada suatu konsep ideologi tertentu, misalnya komunisme mendasarkan ideologinya pada suatu konsep pemikiran Karl Marx. ${ }^{1}$

Berbeda dengan bangsa lain, bangsa Indonesia mendasarkan pandangan hidupnya dalam bermasyarakat, berbangsa dan bernegara pada suatu asas kultur yang dimiliki dan melekat pada bangsa Indonesia sendiri. Nilai-nilai dasar kenegaraan dan kemasyarakatan yang

1 Muhammad Hatta, Politik Kebangsaan dan Ekonomi, (Jakarta: PT. Kompas Media Nusantara, 2015), 393. 
terkandung dalam sila-sila bukanlah hanya konseptual seseorang saja. Melainkan merupakan suatu hasil karya bangsa Indonesia, diangkat dari nilai-nilai kultur yang dimiliki oleh bangsa Indonesia sendiri, melalui proses refleksi filosofis para pendiri negara seperti Soekarno, M. Yamin, M. Hatta, Soepomo serta tokoh pendiri negara lainnya. Secara filosofis, bangsa Indonesia sebelum mendirikan negara adalah sebagai bangsa yang berketuhanan dan berkemanusiaan. Hal ini berdasarkan kenyataan objektif bahwa manusia adalah makhluk Tuhan Yang Maha Esa. Pancasila adalah sebagai dasar filsafat negara dan pandangan filosofis bangsa Indonesia. Hal ini berdasarkan pada suatu kenyataan secara filosofis dan objektif bahwa bangsa Indonesia dalam hidup bermasyarakat dan bernegara mendasarkan pada nilai-nilai yang tertulis dalam sila-sila pancasila yang secara filosofis merupakan filosofi bangsa Indonesia sebelum mendirikan negara. Oleh karena itu, telah merupakan suatu keharusan moral untuk secara konsisten merealisasikannya dalam setiap aspek kehidupan bermasyarakat, berbangsa dan bernegara. ${ }^{2}$

Atas dasar pengertian filosofis tersebut, maka dalam hidup bernegara nilai-nilai pancasila merupakan filsafat negara. Konsekuensinya dalam setiap aspek penyelenggaraan negara harus bersumber pada nilainilai pancasila, termasuk sistem peraturan perundang-undangan di Indonesia. Dengan demikian, dalam realisasi kenegaraan termasuk dalam proses reformasi dewasa, ini merupakan suatu keharusan bahwa pancasila sebagai sumber nilai dalam pelaksanaan kenegaraan, baik dalam pembangunan nasional, politik, hukum, sosial budaya, pertahanan, keamanan dan maupun ekonomi. Berangkat dari permasalahan inilah penulis tertatarik untuk menkaji tentang konsep ekonomi pancasila.

\section{B. Pancasila Secara Kronologis}

\section{Pancasila dalam Pandangan Etimologis}

Istilah pancasila terdapat diperpustakaan Buddha di India yang bersumber dari kitab suci Tri Pitaka yang terdiri dari berbagai macam buku besar Suttha Pitaka, Abidhama dan Vinaya Pitaka. Dalam ajaran Buddha, Pancasyiila yang memberikan lima aturan larangan bagi pemeluk agamanya, yaitu:

1) Larangan mencabut nyawa makhluk hidup atau larangan membunuh.

2) Dilarang mengambil barang yang tidak diberikan. Maksudnya dilarang mencuri.

3) Dilarang berhungan kelamin. Artinya dilarang berzina.

2 Kaelan, Pendidikan Pancasila, (Yogyakarta: Paradigma, 2014), 4-5.

$142 \mid$ JURNAL LISAN AL-HAL 
4) Dilarang berkata palsu. Artinya berdusta.

5) Dilarang minum-minuman yang menghilangkan pikiran. Artinya dilarang minum-minuman keras. ${ }^{3}$

Masuknya kebudayaan India ke Indonesia melalui penyebaran agama Hindu dan Buddha, maka ajaran pancasila Buddhismepun masuk kedalam perpustakaan Jawa, terutama pada zaman Majapahit. Istilah tersebut, dalam khasanah kesusastraan nenek moyang bangsa Indonesia di zaman keemasan kerajaan Majapahit, dibawah raja Hayam Wuruk dan Maha Patih Gajah Mada, dapat ditemukan dalam keropak ${ }^{4}$ Negarakertagama, yang berupa kakawin ${ }^{5}$ dalam pujangga istana bernama Empu Prapanca yang selesai ditulis pada tahun 1365. Dimana dapat ditemukan dalam sarga 53 bait ke 2 yang berbunyi sebagai berikut:

Yatnaggegwani pancasyiila kertasangkarbgisekaka karma, yang artinya Raja menjalankan dengan setia kelima pantangan (Pancasila) begitu pula upacara-upacara ibadat dan penobatan. ${ }^{6}$

Bersamaan dengan runtuhnya kerjaan Majapahit, agama Islam mulai tersebar keseluruh Nusantara, walaupun masih terdapat sisa-sisa pengaruh ajaran Buddha yang dikenal oleh masyarakat Jawa dengan sebutan Pancasila. Lima larangan tertulis dalam ajaran pancasila diantaranya meliputi larangan membunuh, mencuri, berzina, minumminuman keras dan berjudi.

\section{Pancasila dalam Pandangan Historis}

Tanggal 1 Juni 1945 berlangsung proses perumusan pancasila. Berawal ketika dalam sidang BPUKI pertama, Radjiman Widyodiningrat. Dalam sidang tersebut membahas tentang rumusan yang menjadi dasar negara Indonesia, kemudian tampillah tiga orang sebagai pembicara: Mohammad Yamin, Soepomo dan Soekarno. Dalam pidatonya Soekarno secara lisan menyampaikan usulan lima asas sebagai dasar negara Indonesia, yang rumusannya sebagai berikut: 1) Nasionalisme atau kebangsaan Indonesia, 2) Internasionalisme atau Perikemanusiaan, 3)

3 Ibid., 8.

${ }^{4}$ Lihat. Daun Lontar Bertulis (Naskah Kuno di Jawa dan Bali).

5 Arti dari kakawin adalah Sya'ir Pujian. Secara etimologi, kata kakawin sebagai campuran dari kata Sanskerta Kawi "penyair" serta afiks Jawa (Kuna) "ka dan n", yang berarti "karya seorang penyair" atau "syair (puisi) karya penyair". Misalnya cerita tentang Ramayana, Bharatayudha, Arjunawiwaha, Smaradahana, Sutasoma, Nagarakrtagama, dan lain-lain.

${ }^{6}$ Kaelan, Pendidikan Pancasila,13. 
Mufakat atau Demokrasi, 4) Kesejahteraan Sosial, dan 5) Ketuhanan yang Berkebudayaan. ${ }^{7}$

Selanjutnya, Soekarno meringkas lima asas tersebut menjadi Tri Sila yang rumusannya sebagai berikut: 1) Sosio Nasional yaitu Nasionalisme dan Internasionalisme, 2) Sosio Demokrasi yaitu Demokrasi dengan Kesejahteraan Rakyat, dan 3) KetuhananYang Maha Esa.

Adapun Tri Sila tersebut masih diperas lagi menjadi Eka Sila atau Satu Sila yang intinya adalah gotong-royong. ${ }^{8}$

\section{Pancasila dalam Pandangan Terminologis}

Dalam bagian pembukaan UUD 1945 yang terdiri atas empat alenia, tercantum rumusan pancasila sebagai berikut: 1) Ketuhanan Yang Maha Esa, 2) Kemanusiaan yang adil dan beradab, 3) Persatuan Indonesia, 4) Kerakyatan yang dipimpin oleh hikmat kebijaksanaan dalam permusyawaratan perwaakilan, dan 5) Keadilan sosial bagi seluruh rakyat Indonesia. ${ }^{9}$

Rumusan pancasila sebagaimana tercantum dalam pembukaan UUD 1945, inilah yang secara konstitusional sah dan benar sebagai dasar Negara Republik Indonesia, dan disahkan oleh PPKI yang mewakili seluruh rakyat Indonesia. Sejarah telah membuktikan bahwa ketatanegaraan Indonesia dalam upaya bangsa Indonesia mempertahankan Proklamasi dan eksistensi negara dan bangsa Indonesia maka terdapat pula rumusan-rumusan pancasila sebagai berikut:

Pertama, Dalam konstitusi RIS (Republik Indonesia Serikat) yang berlaku pada tanggal 29 Desember 1949 dan Undang-Undang Dasar Sementara yang berlaku pada tanggal 17 Agustus 1950 sampai tanggal 5 Juli 1959, tercantum rumusan pancasila sebagai berikut: 1) Ketuhanan Yang Maha Esa, 2) Peri Kemanusiaan, 3) Kebangsaan, 4) Kerakyatan, dan 5) Keadilan Sosial.

Kedua, Rumusan Pancasila dikalangan masyarakat memiliki rumusan yang beranekaragam, antara lain terdapat rumusan sebagai berikut: 1) Ketuhanan Yang Maha Esa, 2) Peri Kemanusiaan, 3) Kebangsaan, 4) Kedaulatan Rakyat, dan 5) Keadilan Sosial. ${ }^{10}$

7 Cindy Adam, Bung Karno Penyambung Lidah Rakyat Indonesia, (Jakarta: Gunung Agung, 1965), 237.

${ }^{8}$ Kaelan, Pendidikan Pancasila, 15.

${ }^{9}$ Lihat dalam Pembukaan Undang-Undang Dasar 1945 Alinea ke Empat.

10 Ibid., 16-17.

$144 \mid$ JURNAL LISAN AL-HAL 
Berbagai macam rumusan pancasila tersebut yang sah adalah rumusan pancasila yang diakui oleh konstitusional, sebagaimana yang tercantum dalam pembukaan UUD $1945 .{ }^{11}$ Pancasila merupakan salah satu unsur dari empat pilar berbangsa dan bernegara. Diantara empat pilar tersebut adalah Undang-undang Dasar 1945, Pancasila, Binneka Tinggal Ika dan Negara Kesatuan Republik Indonesia.

Pancasila sebagai hasil perenungan jiwa yang mendalam, proses kontemplasi penyelidikan cipta yang teratur dan seksama diatas basis pengetahuan dan pengalaman dasar. Pancasila apabila ditinjau dari perspektif pengetahuan, memiliki dua makna. Pertama, sebagai pensifatan yang sebenarnya dari cita-rindu-kalbu bangsa Indonesia. Kedua, setiap sila dalam pancasila memiliki ikatan kuat dalam suatu kesatuan yang dapat dipertahankan. Misalnya ketuhanan bukan hanya keyakinan biasa, akan tetapi dapat dipahami dengan teori ilmu pengetahuan. Hal ini dapat dibuktikan dengan kebutuhan ciptaan Tuhan terhadap Sang Pencipta. ${ }^{12}$

\section{Wacana Ekonomi Pancasila}

Seiring dengan derasnya arus globalisasi, sistem pasar-pasar mampu termasuk kehidupan ekonomi banyak negara dibelahan dunia, bahkan negara yang semula bertentangan dengan sistem pasar bebas, yakni negara yang berpaham komunisme kemudian secara terus terang telah memberlakukan sistem yang dulu dikutuknya. Adapaun sistem pasar bebas adalah konsepsi derivatif dari sistem liberalisme dan kapitalisme Barat. Ini berarti bahwa terbukanya perdagangan antar negara tanpa batas atau campur tangan siapapun. ${ }^{13}$ Demikian pula yang terjadi pada negara Indonesia. Tidak ada pengecualian yang steril dari pengaruh pasar bebas, meskipun secara normatif unsur bebas tidak diinginkan. Namun kebijakan pragmatis seperti diregulasi (tindakan yang tidak mengikuti aturan semula secara resmi) dan debirokratisasi (penyimpangan aturan dalam birokrasi) nampaknya telah memberikan kelonggaran bagi

11 Hal ini diperkuat dengan ketetapan No. XX/MPRS/1996, dan Inpres No. 12 tanggal 13 April 1968 yang menegaskan bahwa pengucapan, penulisan dan rumusan Pancasila Dasar Negara republik Indonesia yang sah dan benar adalah sebagaimana yang tercantum dalam Pembukaan UUD 1945. 2016), 29.

12 Sukarno, Filsafat Pancasila Menurut Bung Karno, (Jakarta: Media Prassendo,

13 Dawam Rahardjo, Pragmatisme dan Utopia Corak Nasionalisme Indonesia, (Jakarta: LP3ES, 1992), 5. 
berlangsungnya unsur tersebut. Walaupun kebijakan pemerintah tersebut sebenarnya cukup beralasan. ${ }^{14}$

Dalam persaingan sistem pasar, masyarakat mudah terdesak oleh sektor yang besar, padat modal dan padat teknologi. Tidak jarang, skala ekonomi kecil menjadi tidak memiliki kekuatan untuk berpartisipasi dalam persaingan pasar bebas. Oleh karena itu, lebih baik jika pasar bebas tidak dipraktekkan di Indonesia, tetapi yang perlu dipraktekkan adalah sistem ekonomi pasar yang terkendali oleh pemerintah sehingga usaha masyarakat bawah tidak dirugikan. ${ }^{15}$ Dawam Rahardjo mengatakan bahwa Indonesia memang berada dalam kondisi yang dilematis. Menurutnya, pemerintah berada dalam dua kecenderungan, yakni; kecenderungan pragmatis dalam arti mengikuti perkembangan dunia saat ini, dan kecenderungan untuk berpegang teguh pada prinsip yang telah ditetapkan oleh para ekonom Indonesia. Misalnya Bung Hatta yang telah terpengaruh oleh pancasila sebagai ideologi dan UUD 1945 terutama pasal 33, kemudian terbentuk sistem ekonomi pancasila sebagai alternatif dari sistem ekonomi Indonesia. ${ }^{16}$

Pembahasan tentang ekonomi Indonesia tidak bisa lepas dari peristiwa dramatis. Sejak kemerdekaan, krisis ekonomi datang silih berganti. Tahun 1945-1966 masa pancaroba (peralihan musim) perekonomian karena sebagian besar kegiatan domestik ditindih oleh krisis politik, yang tidak pernah bosan hadir di tengah-tengah masyarakat. Tahun 1966 ekonomi ambruk, yang ditandai dengan inflasi nyaris tanpa batas. Penggangguran tak terbendung dan kemiskinan semakin meluas. Bila hanya ada satu perbedaan besar antara sistem ekonomi pancasila dan sistem ekonomi yang masih belum sempurna yang sekarang masih belum berlaku di Indonesia, maka sistem ekonomi pancasila haruslah lebih berkeadilan. ${ }^{17}$ Dalam ketetapan MPR No.II/MPR/1978 disebutkan pancasila merupakan jiwa, kepribadian serta pandangan hidup bangsa Indonesia. Disamping itu juga, pancasila merupakan dasar dan ideologi Negara Republik Indonesia. Oleh karena itu, pancasila merupakan satusatunya asas yang menjadi pedoman dan pegangan bagi warga negara

14 Mohammad Bedjoui, Menuju Tata Ekonomi Baru, (Jakarta: Gunung Agung, 1985), Cet. Ke-2, 15.

15 Mubyarto, Ekonomi Pancasila: Gagasan dan Kemungkinan, (Jakarta: LP3ES, 1987), 7.

16 Ibid., 16.

17 Mubyarto, Ekonomi Pancasila: Gagasan dan Kemungkinan, (Jakarta: LP3ES, 1987), 7.

$146 \mid$ JURNAL LISAN AL-HAL 
Indonesia dalam kehidupan sosial bermasyarakat, berbangsa dan bernegara. 18

Pancasila diterima sebagai satu-satunya asas berbangsa, bermasyarakat dan bernegara, mengimplikasikan bahwa pembangunan nasional juga merupakan proses transformasi kearah masyarakat pancasila. Dengan kata lain, pembangunan nasioanl juga sekaligus merupakan upaya agar nilai yang terkandung dalam lima sila pancasila, tercermin dalam praktik kehidupan sosial sehari-hari. Hal ini menunjukkan bahwa pancasila harus dapat tercemin pada lembagalembaga yang ada, pada nilai-nilai, norma-norma dan pada mekanisme kerja serta aturan permainan yang mengikat pada lembaga-lembaga dalam kehidupan sosial bangsa Indonesia. ${ }^{19}$

Arah pembangunan, sasaran, bentuk dan jiwa aspek kehidupan ekonomi dan prilaku ekonomi, baik dalam tubuh masing-masing maupun dalam keterkaitannya satu dengan yang lain, haruslah jelas agar kehidupan ekonomi yang akan dicapai benar-benar sesuai dengan yang dicita-citakan seperti amanat pancasila dan UUD 1945. Apabila tidak demikian, para pelaku ekonomi tidak akan berperan sebagaimana mestinya dan sasaran kehidupan ekonomi yang dicapai tidak akan sesuai dengan yang dicita-citakan. ${ }^{20}$ Mubyarto menegaskan bahwa sistem ekonomi pancasila berbeda dengan sistem ekonomi koperasi, bahkan selama ini sistem ekonomi pancasila diidentikkan dengan sistem ekonomi koperasi. Padahal kenyataannya emang benar-benar berbeda. ${ }^{21}$

Pasal 33 UUD 1945, yang dirumuskan oleh Bung Hatta sebagai tokoh ekonomi sangatlah jelas mencantumkan tujuan akhir sistem kemakmuran rakyat secara maksimal. Perekonomian harus disusun berdasarkan demokrasi ekonomi. Dimana kemakmuran masyarakat lebih diutamakan dari pada kemakmuran individu. Apabila kemakmuran perorangan yang justru diutamakan, maka pusat produksi akan jatuh ke tangan perorangan yang berkuasa. Jika ini yang terjadi, maka rakyat yang jumlahnya banyak akan tertindas. ${ }^{22}$

${ }^{18}$ Lemhannas (Budisantoso Suryosumarto ), Ekonomi Pancasila, (Jakarta: PT. New Aqua Press, 1989), 3.

${ }_{19}$ Abdul Madjid dan Sri-Edi Swasono, Wawasan Ekonomi Pancasila, (Jakarta: UI Press, 1998), 1.

${ }^{20}$ Ibid., 5.

${ }^{21}$ Mubyarto, Ilmu Ekonomi, Ilmu Sosial dan Keadilan, (Jakarta:Yayasan Agro Ekonomika, 1980), 88.

22 Mubyarto, Ekonomi Pancasila, 126. 
Kemerdekaan yang diproklamasikan pada tahun 1945 telah memberikan kesempatan kepada bangsa Indonesia untuk mewujudkan cita-citanya "Keadilan sosial bagi seluruh rakyat Indonesia dalam wadah negara yang merdeka, bersatu, berdaulat, adil dan makmur berdasarkan Pancasila“. Tata ekonomi Indonesia selalu ditekankan berdasarkan Pancasila. Hal ini merupakan argumentasi yang sangat bagus. Sistem perekonomian yang dijadikan sebagai pedoman dasar bagi tata susunan ekonomi nasional dan sikap mental yang mendasarinya. Idealnya sistem ekonomi Indonesia adalah suatu tata ekonomi yang dijiwai oleh ideologi pancasila, suatu ekonomi nasional yang merupakan usaha bersama dan yang berasaskan kekeluargaan dan kegotong-royongan dibawah pimpinan pemerintah. Sistem ekonomi pancasila secara finansial tidak begitu menguntungkan, tetapi lebih bersifat manusiawi, karena mengutamakan unsur sosial, keadilan dan persaudaraan, atau dapat disebut tata ekonomi yang bermoral. Inilah cita-cita bangsa Indonesia, pedoman yang normatif, tetapi sayangnya belum menjadi kenyataan. ${ }^{23}$ Sistem ekonomi pancasila sangat berkaitan dengan sistem ekonomi kerakyatan, didalam sistem ekonomi pancasila itu digali dan dibangun dari nilai-nilai yang dianut dalam masyarakat Indonesia. Beberapa prinsip dasar yang ada dalam sistem ekonomi pancasila tersebut antara lain berkaitan dengan prinsip kemanusian, nasionalisme ekonomi, demokrasi ekonomi yang diwujudkan dalam ekonomi kerakyatan dan keadilan.

\section{Ikhtilaf Penafsiran}

Sejak tahun 1980-an, istilah ekonomi pancasila identik dengan tokoh yang bernama Mubyarto. Beliau menegaskan bahwa ekonomi pancasila harus terkait langsung dengan ekonomi masyarakat kecil dan bertumpu pada moralitas sosial, egalitarianisme, nasionalisme ekonomi, koperasi dan keseimbangan antara perencanaan pusat dan daerah. ${ }^{24}$

Pada awalnya, yang mengintroduksikan ekonomi pancasila adalah Emil Salim, kisaran tahun 1965. Pembahasan mengenai model sistem dan teori mengenai sistem ekonomi yang sesuai dengan letak geografis negara Indonesia. Pada kerangkanya, Emil Salim membahas model sistem ekonomi, yaitu; ekonomi swasta, ekonomi kontrol, ekonomi kolektif dan ekonomi perencanaan sentral. Emil Salim awalnya menggunakan istilah

23 Tarli Nugroho, Polemik Ekonomi Pancasila: Pemikiran dan Catatan, 1965-1985, (Yogyakarta: Mubyarto Institute, 2016), 452.

24 Abdurrahman Wahid, Islamku, Islam Anda, Islam Kita, (Jakarta: Projeck Demokrasi, 2011), 183.

$148 \mid$ JURNAL LISAN AL-HAL 
Sistem Ekonomi Sosialisme Pancasila, namun pada artikel yang ditulis berikutnya, yang sangat menekankan pentingnya pemerintah memikirkan masalah pembangunan ekonomi, untuk mengimbangi keberhasilan Indonesia dalam pembangunan politik, istilah yang digunakan Emil Salim berubah menjadi Ekonomi Pnacasila. ${ }^{25}$

Istilah ekonomi pancasila, terdapat perbedaan mendasar antara istilah ekonomi pancasila yang dimaksudkan oleh Emil Salim dengan Mubyarto. Mubyarto menggunakan ekonomi pancasila sebagai bentuk teori kritis, untuk mengkritik teori ekonomi arus utama (mainstream economis), dalam hal ini Neoklasik. Berbeda dengan Mubyarto, Emil Salim menerjemahkan istilah ekonomi pancasila sebagai gagasan mengenai sistem perekonomian atau politik perekonomian. ${ }^{26}$

Perbedaan antara ekonomi pancasila versi Emil Salim dengan ekonomi pancasila perspektif Mubyarto, sebenarnya secara umum terletak pada dua pendekatan yang berbeda, yakni antara pendekatan konseptual dengan pendekatan politik. Pertama, Pendekatan konseptual yang dimaksudkan Emil Salim tidak sedang bertendensi memperkenalkan teori ekonomi baru dan juga tidak sedang berusaha melakukan kritik teori. Emil menganggap bahwa ilmu ekonomi itu universal. Jika terdapat ketidaksesuaian antara teori ekonomi dengan praktik, maka kekeliruan terletak pada praktiknya. Jadi, menurut Emil tidak ada gunanya menyusun teori baru karena memang ilmu ekonomi tidak ada yang keliru, hanya pengimplementasiannya saja yang mungkin keliru. Sebagaimana pernyataan Mubyarto (awal 1980-an), Emil Salim tidak pernah mengemukakan pandangan bahwa ada yang keliru dari ilmu ekonomi mainstream (neoklasik). ${ }^{27}$ Sementara itu, Mubyarto menempatkan gagasan ekonomi pancasila pada posisi teoritis. Sebagaimana dalam pidato pengukuhannya sebagai guru besar di Fakultas Ekonomi Universitas Gajah Mada:

"Tujuan yang berbeda tidak dapat dicapai hanya dengan mengubah kebijaksanaan dan strategi, tetapi harus dengan mengubah teorinya. Tidakkah sudah tiba saatnya, ekonom Indonesia mulai mawas diri dan

25 Emil Salim, "Politik dan Ekonomi Panjtasila”, dimuat dalam Widjojo Nitisastro dkk., Masalah-Masalah Ekonomi dan Faktor-faktor IPOLOS (Ideologi, Politik, Sosial), (Jakarta: LEKNAS, 1965), 81-97.

26 Tarli Nugroho, Polemik Ekonomi Pancasila: Pemikiran dan Catatan, 1965-1985, (Yogyakarta: Mubyarto Institute, 2016), 12

27 Wawancara Majalah Prisma dengan Emil Salim, " Emil Salim: Bukan Kesalahan Ilmu Ekonomi”, dalam Majalah Prisma, No. 1/IX, Januari 1980, 56-61. 
mempertanyakan relevansi teori Neoklasik Ortodoks sebagai ilmu yang mendasari berbagai kebijaksanaan dan strategi ekonomi."28

Pidato tersebut menunjukkan bahwa Mubyarto melakukan kritikan terhadap teori ekonomi neoklasik (maintream economis), yang dianggap bukan hanya tidak mampu mendistribusikan porsi ekonomi secara merata, tetapi sebagai sebuah masalah yang dihadapi perekonomian Indonesia pada tahun 1970-an hingga saat ini. Teori tersebut, secara konseptual tidak bersifat mendukung terhadap gagasan keadilan sosial. Dalam pandangan Mubyarto, bukan hanya diperlukan perubahan kebijakan untuk mendistribusikan porsi ekonomi nasional secara merata dan adil, tetapi diperlukan juga sebuah teori ekonomi baru untuk melakukannya. Kedua, menggunakan pendekatan politik. Penjelasan politis yang melatar belakangi munculnya istilah ekonomi pancasila pada tahun 1965. Dengan pendekatan ini, istilah ekonomi pancasila bisa dikaji sebagai bentuk usaha untuk menutupi lapangan pemikiran ekonomi dari pengaruh ideologi yang dianggap bertentangan dengan kemurnian pancasila. Ekonomi pancasila dimunculkan sebagai barrier agar masyarakat tidak lagi menggunakan idiom-idiom Sosialis, Komunis dan Islamis. Kekhawatiran itu benar-benar terjadi pasca lengsernya Soekarno, sekaligus sebagai penjelasan tambahan tentang jeda panjang antara tahun 1966 hingga istilah ekonomi pancasila muncul kembali pada akhir tahun 1970-an. ${ }^{29}$

Perbedaan antara gagasan ekonomi pancasila versi Mubyarto dengan Emil Salim terletak pada istilah ekonomi pancasila yang dipakai pada awal dekade tahun 1965 dengan tahun 1980-an. Jika pada awalnya, istilah ekonomi pancasila dimunculkan sebagai basis legitimasi bagi jalan ekonomi yang kemudian ditempuh oleh Orde Baru, maka ditangan Mubyarto dan teman-temannya ekonomi pancasila pada tahun 1980-an justru dijadikan senjata untuk mengkritik pemerintahan Orde Baru. Terdapat tiga hal yang membuat rezim Orde Baru bereaksi serius terhadap gagasan ekonomi pancasila, yaitu:

a. Ekonomi pancasila secara politis telah dimaksudkan sebagai kritik terhadap jalan pembangunan ekonomi yang sedang dipraktekkan pemerintah, sehingga tentu saja kritik tersebut tidak disukai.

28 Mubyarto, Gagasan dan Metode Berpikir Tokoh-tokoh Besar Ekonomi dan Penerapannya Bagi Kemajuan Kemanusiaan, (Yogyakarta: BPFE, 1979). Ini adalah naskah pidato pengukuhan Mubyarto sebagai Guru Besar Fakultas Ekonomi Universitas Gajah Mada, diucapkan pada tanggal 19 Mei 1979.

29 Ibid., 24.

$150 \mid$ JURNAL LISAN AL-HAL 
b. Sejak tahun 1978 pemerintah Orde Baru memulai usaha untuk memonopoli dan mengkonsolidasi produksi tafsir atas pancasila.

c. Penggunaan label pancasila dalam istilah ekonomi pancasila dari sudut pandang pemerintah sepertinya telah mendatangkan trauma. Jika kembali pada tahun 1966, pemerintah menjadikan pancasila sebagai alat untuk mendelegitimasi rezim Soekarno, lalu tiba pada awal dekade 1980-an sekelompok ekonom menggunakan label tersebut sebagai kritik terhadap pemerintah. ${ }^{30}$

Menurut Gunawan Sumodiningrat, ekonomi pancasila sebagai perjuangan, seperti perjuangan untuk merealisasikan cita-cita kemerdekaan sehingga tercapai Indonesia yang benar-benar merdeka, bersatu berdaulat adil dan makmur. Menurutnya, ekonomi pancasila, sejalan dengan perjuangan kedaulatan politik, menetapkan pembangunan ekonomi nasional melalui perjuangan kedaulatan ekonomi. ${ }^{31}$ Sedangkan menurut Sri-Edi Swasono, ekonomi pancasila merupakan ekonomi sosialistis yang berakar pada adat-istiadat Indonesia (Kolektivisme) dan pedoman perjuangan bangsa yang berorientasi pada kelima sila pancasila. ${ }^{32}$ Bahkan menurut Gunawan Sumodiningrat bahwa ekonomi pancasila bukan hanya untuk perjuangan bangsa, melainkan sebagai pandangan filsafat dalam kehidupan. Sistem ekonomi yang dipengaruhi atas diterimanya pancasila sebagai asas atau dasar negara Indonesia. ${ }^{33}$ Namun bagi Mubyarto, ekonomi pancasila didefinisikan sebagai sistem ekonomi yang dijiwai oleh ideologi pancasila, yaitu sistem ekonomi yang merupakan usaha bersama yang berasaskan kekeluargaan dan ketogotong-royongan nasional. Kegotong-royongan nasional, bukan hanya kegotong-royongan di pedesaan, di kampung, tetapi kegotong-royongan pada tingkat nasional. ${ }^{34}$

\section{Prinsip Dasar Ekonomi Pancasila}

Pancasila merupakan falsafah sekaligus sebagai sumber hukum segala kebijakan yang menjadi rujukan penyelenggaraan negara. Disinilah kelemahan bangsa Indonesia, ketika diwilayah oprasional meskipun banyak kalangan yang mengakui sebagai pengikut setia pancasila

30 Ibid., 25.

${ }^{31}$ Abdul Madjid dan Sri-Edi Swasono, Wawasan Ekonomi,18.

32 Ibid., 19.

33 Gunawan Sumodiningrat, Sistem Ekonomi Pancasila dalam Perspektif, (Jakarta: Impac Wahana Cipta, 1999), Cet. Ke-1, 1.

34 Abdul Madjid dan Sri-Edi Swasono, Wawasan Ekonomi Pancasila, (Jakarta: UI Press, 1998), 32-33. 
sekalipun, bisa berbeda bahkan berlawanan. Hal ini tidak hanya terkait hal yang abstrak, namun yang tidak nyata juga termasuk didalamnya. Misalkan dalam mengamalkan sila pertama Ketuhanan Yang Maha Esa. Bagaimana menyikapi kerukunan antarumat beragama? Bagaimana mengatur perekonomian negara? sedangkan modal asing dan pasar bebas telah menguasai sumber daya bangsa Indonesia. Bagaimana mewujudkan sila kelima? Keadilan Sosial Bagi Seluruh Rakyat, ketika banyak kalangan meributkan orang miskin dilarang sakit. Hal ini mengindisikan bahwa pengalaman pancasila tidak boleh berhenti pada tataran makro, sekedar menyepakati empat pilar berbangsa dan bernegara, tetapi juga perlu menyamakan persepsi ditataran mikro, operasional the road map atau proses mewujudkan kehidupan berbangsa dan bernegara sesuai dengan pancasila. $^{35}$

UUD 1945 telah mengalami perubahan secara drastis, seiring dengan diamandemennya Undang-Undang Dasar 1945 pada tahun 2002. Namun perubahan tersebut tidak sampai merubah terhadap formula pancasila dan pembukaan UUD 1945. Salah satu pasal yang mengalami perubahan pada tahun 2002 adalah pasal 33 dan 34 UUD 1945. ${ }^{36}$

Dalam pasal 33 UUD 1945 tercantum dasar demokrasi ekonomi, produksi dikerjakan oleh semua untuk keseluruhan dibawah pimpinan atau pemilikan anggota masyarakat. Kemakmuran masyarakatlah yang diutamakan, bukan kemakmuran individu. Oleh sebab itu, sebagai usaha bersama berdasar azas kekeluargaan. Bangunan perusahaan yang sesuai dengan prinsip tersebut adalah koperasi. Peran perekonomian memang sangat besar didalam kehidupan setiap bangsa. ${ }^{37}$

Pilihan sistem ekonomi menjadi tulang punggung mewujudkan kesejahteraan. Bahkan sistem ekonomilah yang menjadi landasan kebijakan kesejahteraan sosial. Hal ini terlepas bahwa kesejahteraan rakyat masih tetap merupakan tujuan utama setiap bangsa. Landasan konstitusional ekonomi pancasila adalah dipergunakan UUD 1945 terutama pasal 33 ayat 1, 2 dan 3 yang merupakan dasar dari demokrasi ekonomi dalam negara Indonesia. Pada pasal tersebut dinyatakan bahwa: 1) Perekonomian disusun sebagai usaha bersama berdasar atas asas kekeluargaan, 2) Cabang-cabang produksi yang penting bagi negara dan yang menguasai hajat hidup orang banyak dikuasai oleh negara, dan 3)

35 Sulastomo, Cita-cita Negara Pancasila, (Jakarta: PT. KOMPAS Media Nusantara, 2014), 6.

36 Ibid., 44.

37 Ibid., 45.

152 JURNAL LISAN AL-HAL 
Bumi dan air kekayaan alam yang terkandung didalamnya dikuasai oleh negara dan dipergunakan sebesar-besarnya untuk kemakmuran rakyat. 38

Berdasarkan pasal 33 tersebut, maka dapat dikemukakan bahwa untuk memecahkan masalah ekonomi adalah ditangani oleh koperasi, swasta dan pemerintah. Usaha yang relevan dengan ayat 1 adalah koperasi. Koperasi dalam bentuk kerjasama antar manusia untuk bekerja sama menolong diri sendiri. Untuk memupuk solidaritas antar anggota dalam kelompok kekeluargaan, semangat kekeluargaan atau solidaritas inilah moralitas ekonomi pancasila, tapi bukan berarti ekonomi keluarga dalam arti mementingkan keluarga atau kelompok sendiri. ${ }^{39}$ Ayat 2 menunjukkan adanya peranan pemerintah dalam kegiatan dan kehidupan pemerintahan, tetapi dalam batas-batas tertentu, yaitu hanya pada cabang-cabang produksi yang terpenting bagi negara dan yang menguasai hajat hidup orang banyak. Tentu saja kegiatan ekonomi diluar sektor pemerintah dan koperasi, ditangani oleh perusahaan swasta. Perusahaan sebenarnya dapat dilaksanakan berdasarkan jiwa ayat 1 , yaitu berazaskan kekeluargaan. ${ }^{40}$

Pengertian dikuasai negara dalam ayat 2 dan 3 dalam pasal 33 UUD 1945 tersebut tidak berarti bahwa negara melakukan penguasaan atas semua kegiatan ekonomi yang menguasai hajat hidup orang banyak. Negara bukan menjadi pengusaha, sebab dalam demokrasi ekonomi justru menghindarkan diri dari unsur monopoli negara. ${ }^{41}$ Lebih tepatnya, jika penguasaan negara diartikan bahwa negara berhak dan berkewajiban mengatur dan mengarahkan kebijakan ekonomi secara tepat, sehingga dapat menghindari terjadinya: 1) Penghisapan kelompok lemah oleh pemilik modal; yang pada dasarnya telah dijamin oleh pasal 27 ayat 2 UUD 1945, sehingga kewajiban pemerintahlah dengan legalitas kekuasaan yang dimilikinya untuk mengatur perekonomian negara, 2) Konsentrasi modal disatu tangan atau kelompok tertentu, sehingga menjurus pada monopoli usaha yang bisa menciptakan penghisapan pemilik modal terhadap pihak yang lemah. ${ }^{42}$

38 Ibid., 33.

39 Mohammad Hatta, Pelaksanaan Undang-Undang Dasar 1945 pasal 33, Kongres ISEI VIII, Juni 1979.

40 Ibid., 33-34.

41 Demokrasi ekonomi berarti tidak adanya tempat bagi ciri-ciri negatif liberalisme-kapitalisme yang menciptakan survival of the fittest, maupun ekonomi sosialistis-komunis yang bersifat etatisme (monopoli negara) maupun penguasaan ekonomi monopoli.

42 Tarli Nugroho, Polemik Ekonomi, 153. 


\section{Sistem Ekonomi Pancasila}

Sistem ekonomi pancasila berisi aturan prilaku ekonomi yang mengacu pada ideologi bangsa Indonesia, yaitu pancasila. Dalam sistem ekonomi pancasila pemerintah dan masyarakat berpihak kepada kepentingan ekonomi rakyat sehingga terwujud kemerataan sosial dalam kemakmuran dan kesejahteraan. Emil Salim menyatakan bahwa ekonomi pancasila itulah koperasi yang dikembangkan, tetapi sekaligus fungsi koperasi adalah mengarahkan perkembangan ekonomi Indonesia kearah sistem ekonomi pancasila. Oleh karena itu, hanya dalam sistem ekonomi pancasila inilah koperasi dapat tumbuh dan berkembang, penuh isi dan integritas. ${ }^{43}$

Sistem ekonomi pancasila mencakup kesepakatan dan aturan main sebagai berikut:

a. Ketuhanan Yang Maha Esa: perilaku setiap warga negara digerakkan oleh rangsangan ekonomi, sosial dan moral.

b. Kemanusiaan yang adil dan beradab: ada tekad seluruh bangsa untuk mewujudkan kemerataan sosial.

c. Persatuan nasional: nasionalisme ekonomi.

d. Kerakyatan yang dipimpin oleh hikmat kebijaksanaan dalam permusywaratan/ perwakilan: demokrasi.

e. Keadilan sosial bagi seluruh rakyat Indonesia: desentralisasi dan otonomi daerah. 44

Perkembangan yang berlangsung selama kurun waktu 1968-1978 adalah gerak reaksi terhadap perkembangan ekonomi selanjutnya. Berbagai kehancuran yang diderita ekonomi perlu dipulihkan. Landasan ekonomi perlu dikokohkan untuk memungkinkan pertumbuhan selanjutnya. Oleh karena itu, Emil Salim juga memberikan konsepsi tentang sitem ekonomi pancasila sebagai berikut:

a. Manusia pancasila harus menyeimbangkan antara kerja dengan doa sebagai makhluk yang berketuhanan, berprikemanusiaan, berkedaulatan rakyat, berkeadilan sosial dan berkebangsaan.

b. Ekonomi pancasila tidak mentolerir cara-cara produksi yang mengeksploitasi sesama manusia.

${ }^{43}$ Sri-Edi Swasono, Sistem Ekonomi dan Demokrasi Ekonomi, (Jakarta: UI Press, 1987), Cet. Ke-2, 122.

${ }^{44}$ Gunawan Sumodiningrat, Sistem Ekonomi, 59.

$154 \mid$ JURNAL LISAN AL-HAL 
c. Sistem ekonomi yang memungkinkan pengembangan unsur kemanusiaan dan memperoleh akar yang kuat dalam hati sanubari masyarakat Indonesia.

d. Sistem ekonomi yang cenderung berada ditengah antara sistem ekonomi terpimpin dengan sistem ekonomi pasar dalam posisi equilibrum.

e. Sistem ekonomi yang secara ideologis menganut paham demokrasi ekonomi asas perikehidupan keseimbangan.

f. Sebuah sistem ekonomi yang mengarahkan perkembangan ekonomi ke arah yang sesuai dengan prioritas dalam perencanaan.

g. Sistem ekonomi yang memiliki unsur pasar bekerja aktif dan mekanisme harga terpakai untuk alokasi sumber-sumber dana dan faktor produksi. ${ }^{45}$

Sumber lain, sistem ekonomi Indonesia mengacu pada nilai-nilai pancasila sebagai ideologi bangsa Indonesia yang tujuannya adalah mewujudkan keadilan sosial bagi seluruh rakyat Indonesia. Salah satu nilai intrinsiknya adalah ekonomi pancasila memiliki nilai-nilai dasar sebagai berikut:

a. Ketuhanan, dimana roda kegiatan ekonomi bangsa digerakkan oleh rangsangan ekonomi, sosial dan moral.

b. Kemanusiaan, yaitu kemerataan sosial, yakni ada kehendak kuat masyarakat untuk mewujudkan kesejahteraan sosial, tidak membiarkan terjadinya ketimpangan ekonomi dan kesenjangan sosial.

c. Kepentingan nasional (nasionalisme ekonomi), didalam era globalisasi makin jelas urgensi terwujudnya perekonomian nasional yang kuat dan mandiri.

d. Kepentingan rakyat banyak, demokrasi ekonomi berdasar kerakyatan dan kekeluargaan, koperasi dan usaha-usaha kooperatif menjiwai perilaku ekonomi individu dan kolektif.

e. Keadilan sosial, yaitu keseimabangan yang harmonis, efisien dan adil antara perencanaan nasional, desentralisasi ekonomi, otonomi yang luas, bebas dan bertanggungjawab menuju terwujudnya keadilan sosial bagi seluruh rakyat Indonesia. ${ }^{46}$

\section{Karakteristik Ekonomi Pancasila}

Istilah ekonomi pancasila diidentikkan dengan demokrasi ekonomi. GBHN/TAP MPR IV/1978, memberikan ciri-ciri positif yang harus

45 Emil Salim, Sistem Ekonomi Pancasila, 123

${ }^{46}$ http://www.ekonomikerakyatan.ugm.ac.id/My\%20Web/sembul//59.htm. 
dilaksanakan dan ciri-ciri negatif yang semestinya dihindari. Macamnacam cirinya adalah sebagai berikut: Pertama, Ciri-ciri Positif: 1) Warga negara memiliki kebebasan dalam memilih pekerjaan yang dikehendaki serta mempunyai hak akan pekerjaan dan penghidupan yang layak, 2) Sumber-sumber kekayaan dan keuangan negara digunakan dengan pemufakatan lembaga-lembaga perwakilan rakyat, serta pengawasan terhadap kebijaksanaannya ada pada lembaga perwakilan rakyat pula, 3) Bumi dan air dan kekayaan alam yang terkandung didalamnya dikuasai negara dan dipergunakan untuk sebesar-besarnya kemakmuran rakyat, 4) Perekonomian disusun sebagai usaha bersama atas asas kekeluargaan, 5) Cabang-cabang produksi yang penting bagi negara dan menguasai hajat hidup orang banyak dikuasai negara, 6) Hak milik individu diakui dan pemanfaatannya tidak boleh bertentangan dengan kepentingan masyarakat, 7) Potensi, inisiatif dan daya kreasi setiap warga negara diperkembangkan sepenuhnya dalam batas-batas yang tidak merugikan kepentingan umum, dan 8) Fakir miskin dan anak-anak yang terlantar dipelihara oleh negara.

Kedua, Ciri-ciri Negatif yang harus dihindari diantaranya yaitu: 1) Sistem etatisme, ekonomi serba dikuasai negara sehingga mematikan usaha-usaha disektor swasta dan koperasi, unit-unit ekonomi diluar sektor negara, 2) Sistem free-fight liberalism yang menimbulkan eksploitasi terhadap manusia seperti penghisapan kelompok bermodal terhadap kelompok lemah, dan 3) Pemusatan ekonomi pada suatu kelompok dalam bentuk monopoli yang merugikan masyarakat. ${ }^{47}$

Jadi, jelaslah yang dimaksud ciri positif. Tidak lain merupakan pengulangan saja dari yang termaktub dalam Undang-Undang Dasar 1945 khususnya pasal 33 pada ayat 1, 2 dan 3, pasal 23 ayat 4, pasal 27 ayat 2, pasal 28 ayat 4 dan pasal 34 ayat 8.48

Dalam formulasi yang lain, Mubyarto menyebutkan ciri-ciri sistem ekonomi pancasila sebagai berikut:

a. Roda perekonomian digerakkan oleh rangsangan ekonomi, sosial dan moral.

b. Ada kehendak kuat dari seluruh anggota masyarakat untuk mewujudkan keadaan kemerataan sosial ekonomi.

c. Prioritas kebijaksanaan ekonomi adalah pengembangan ekonomi nasional yang kuat dan tangguh, yang berarti nasionalisme selalu menjiwai setiap kebijaksanaan ekonomi.

47 Tarli Nugroho, Polemik Ekonomi, 154-155.

48 Ibid., 160.

$156 \mid$ JURNAL LISAN AL-HAL 
d. Kooperasi merupakan suko guru perekonomian nasional.

e. Adanya keseimbangan yang jelas, tegas sentralisme dan desentralisme kebijaksanaan ekonomi untuk menjamin keadilan ekonomi, keadilan sosial sekaligus menjaga prinsip efisiensi serta pertumbuhan ekonomi. 49

Ciri khas atau karakteristik lain ekonomi pancasila adalah semangat solidaritas sosial untuk mencapai masyarakat yang berkeadilan sosial, seperti yang termaktub pada sila kelima dalam pancasila. Masyarakat pancasila yang berkeadilan adalah masyarakat yang sosialistik dimana nasib rakyat yang tertinggal menadapat perhatian besar. Inilah yang disebut dalam pasal 34 UUD 1945, yang berbunyi bahwa fakir miskin dan anak-anak terlantar dipelihara oleh negara. Bahkan yang tercantum pada pasal 33, dianggap sebagai pedoman dasar pengelolaan perekonomian Indonesia..$^{50}$

Berbagai karakteristik yang dikemukakan, tampaklah bahwa sistem ekonomi pancasila mengandung nilai-nilai ke Indonesiaan, yaitu kekeluargaan dan kemandirian sebagai jati diri budaya bangsa. Kemandirian yang dibangun dengan semangat kekeluargaan itu tidak bisa dipisahkan dari akar budaya dan nilai-nilai religius yang hidup dalam masyarakat. Demokrasi politik, tidak akan mengabaikan cita-cita demokrasi ekonomi. Demokrasi ekonomi, tidak membunuh demokrasi politik. Dengan landasan berpikir demikianlah, demokrasi politik dan demokrasi ekonomi hendak dibangun dalam suasana lingkungan kehidupan simbiosis-mutualisme yang saling mendukung dan tidak saling menegasikan. ${ }^{51}$

\section{Simpulan}

Konsep ekonomi pancasila merupakan perilaku ekonomi yang berpondasikan terhadap ideologi negara Indonesia, yakni pancasila. Ekonomi pancasila merupakan usaha bersama yang berasaskan kegotongroyongan nasional bertujuan untuk mewujudkan keadilan sosial dalam kemakmuran dan kesejahteraan bersama. Hal ini sebagaimana yang tertuang dalam sila kelima pancasila "Keadilan Sosial bagi Seluruh Rakyat Indonesia". Ini merupakan tujuan utama dari terbentuknya konsep ekonomi pancasila. Selain itu, konsep ekonomi pancasila merupakan

49 Yudi Latif, Negara Paripurna: Historis, Rasionalitas dan Aktualitas Pancasila, (Jakarta: PT. Gramedia Pustaka, 2015), 587.

50 Abdul Madjid dan Sri-Edi Swasono, Wawasan Ekonomi, 93-94.

51 Yudi Latif, Negara Paripurna, 592. 
sistem ekonomi yang digali dan dibangun dari nilai-nilai yang dianut dalam masyarakat Indonesia. Beberapa prinsip dasar yang ada dalam sistem ekonomi pancasila adalah berkaitan dengan prinsip kemanusiaan, nasionalisme ekonomi, demokrasi ekonomi yang diwujudkan dalam ekonomi kerakyatan dan keadilan. Tentu, konsep ekonomi pancasila bukan hanya sekedar teori praktis belaka dalam prilaku ekonomi, tetapi merupakan suatu disiplin ilmu ekonomi berprinsip guna melakukan alokasi sumber daya yang langka dan terbatas untuk dimanfaatkan secara rasional sehingga mencapai hasil yang maksimal bagi kesejahteraan seluruh rakyat Indonesia.

\section{DAFTAR PUSTAKA}

Adam Cindy, Bung Karno Penyambung Lidah Rakyat Indonesia, Jakarta, Gunung Agung, 1965.

Bedjoui Mohammad, Menuju Tata Ekonomi Baru, Jakarta, Gunung Agung, 1985.

Gunawan Sumodiningrat, Sistem Ekonomi Pancasila dalam Perspektif, Jakarta, Impac Wahana Cipta, 1999.

Hatta Muhammad, Politik Kebangsaan dan Ekonomi, Jakarta, PT. Kompas Media Nusantara, 2015.

Pelaksanaan Undang-Undang Dasar 1945 pasal 33, Kongres

ISEI VIII, Juni 1979.

Kaelan, Pendidikan Pancasila, Yogyakarta, Paradigma, 2014.

Latif Yudi, Negara Paripurna: Historis, Rasionalitas dan Aktualitas Pancasila, Jakarta, PT. Gramedia Pustaka, 2015.

Lemhannas (Budisantoso Suryosumarto ), Ekonomi Pancasila, Jakarta, PT. New Aqua Press, 1989.

Mubyarto, Ekonomi Pancasila: Gagasan dan Kemungkinan, Jakarta: LP3ES, 1987.

Gagasan dan Metode Berpikir Tokoh-tokoh Besar Ekonomi dan Penerapannya Bagi Kemajuan Kemanusiaan, Yogyakarta: BPFE, 1979.

Ilmu Ekonomi, Ilmu Sosial dan Keadilan, Jakarta, Yayasan Agro

Ekonomika, 1980.

Nugroho Tarli, Polemik Ekonomi Pancasila: Pemikiran dan Catatan, 19651985, Yogyakarta, Mubyarto Institute, 2016.

Rahardjo Dawam, Pragmatisme dan Utopia Corak Nasionalisme Indonesia, Jakarta, LP3ES, 1992.

$158 \mid$ JURNAL LISAN AL-HAL 
Sri-Edi Swasono dan Abdul Madjid, Wawasan Ekonomi Pancasila, Jakarta: UI Press, 1998.

Sukarno, Filsafat Pancasila Menurut Bung Karno, Jakarta, Media Prassendo, 2016.

Sulastomo, Cita-cita Negara Pancasila, Jakarta, PT. KOMPAS Media Nusantara, 2014.

Swasono Sri-Edi, Sistem Ekonomi dan Demokrasi Ekonomi, Jakarta: UI Press, 1987.

Wahid Abdurrahman, Islamku, Islam Anda, Islam Kita, Jakarta, Projeck Demokrasi, 2011.

Widjojo Nitisastro dkk., Masalah-Masalah Ekonomi dan Faktor-faktor IPOLOS (Ideologi, Politik, Sosial), Jakarta, LEKNAS, 1965.

Majalah Prisma, No. 1/IX, Januari 1980.

http://www.ekonomikerakyatan.ugm.ac.id/My\%20Web/sembul//59.htm. 
"Konsep Ekonomi Pancasila"

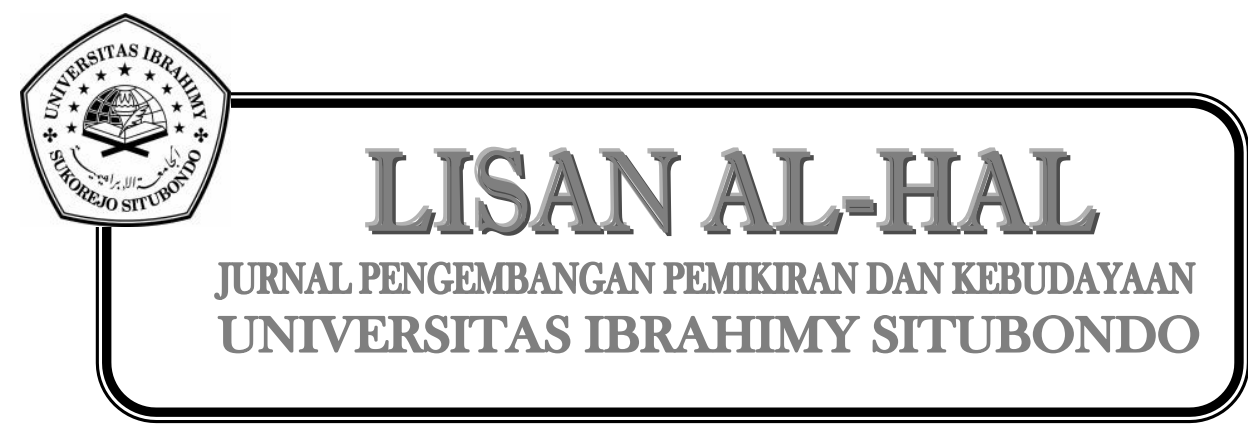

$160 \mid$ JURNAL LISAN AL-HAL 